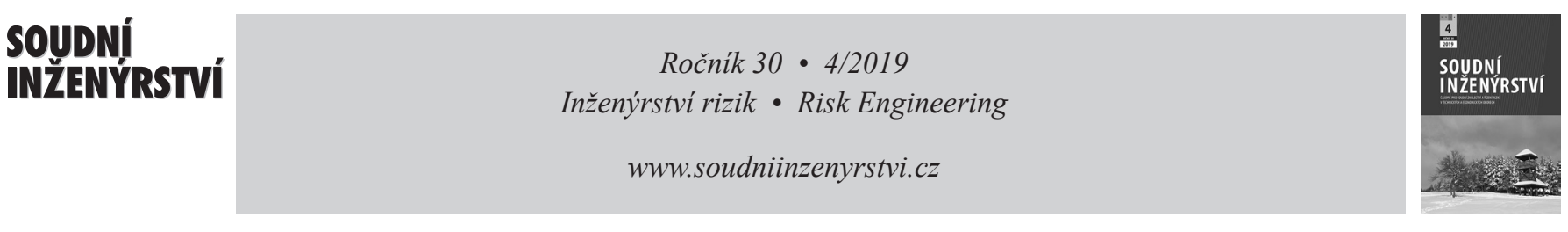

\title{
Spolehlivost analýzy rizika
}

\section{Reliability of Risk Analysis}

Radim Roudný*

Univerzita Pardubice, Fakulta ekonomicko-správní

\begin{abstract}
Abstrakt
V úvodu je diskutován pojem riziko a jeho použivání. Je uvedeno tř́idění věd v souvislosti se spolehlivostí tvorby modelů. Dále př́spěvek uvádí proces analýzy rizika a jeho interakci s návrhem prevence. Jsou kategorizovány jednotlivé zdroje, informace se zdůrazněním neurčitosti celého procesu analýzy rizika. Je zdůrazněn princip neurčitého hodnocení a jednoznačného rozhodnutí. V modelování rizika i prevence je důležitá volba faktorů pokud možno co nejjednodušší modely, které ovšem musí mít věcný smysl, doporučeny jsou lineární modely. Práce s neurčitostí je považována za základní zásadu hodnocení rizika a rozhodováni o prevenci. Diskutována je neurčitost informací o minulosti. Zdůrazněna je úloha subjektivního hodnocení rizika a je naznačena práce s tak zvanými ř́́dkými stupnicemi. Na závěr jsou diskutovány př́íklady ze statistiky požárů ČR. Článek byl prezentován na konferenci Crissiscon v Uherském Hradišti ve dnech 12. a 13. září 2019.
\end{abstract}

Klíčová slova: riziko, prevence, informace, spolehlivost, subjektivní vliv, statistika požárů.

\section{1. ÚVOD}

Riziko hodnotíme v období před nežádoucí událostí (dále NU), pokud NU, nebo její vyšší stupně mimořádná událost či krize, nastane, pak to je konkrétní událost. Riziko je potenciální, je to předpoklad, že něco nastane. Norma ČSN 31000 [4] v bodu 3.2 uvádí „,management rizik - koordinační činnosti pro vedení a řízení organizace s ohledem na rizika“, což zahrnuje celé bezpečnostní řízení organizace před NU. Hodnocení rizika není samoúčelné, praktický smysl je jeho

využití při rozhodování o prevenci.

Skutečnost, že riziko popisuje budoucnost, zásadním způsobem ovlivňuje jeho neurčitost. Stupeň rizika vyjadřuje míru ohrožení, předpokládané újmy chráněného aktiva (dále CHA), může být

\begin{abstract}
The concept of risk and its use is discussed in the introduction. The classification of sciences in relation to the reliability of modeling is presented. Furthermore, the paper presents the process of risk analysis and its interaction with the prevention proposal. Individual sources and information are categorized, emphasizing the uncertainty of the entire risk analysis process. The principle of vague evaluation and unambiguous decision is emphasized. In modeling both risk and prevention, it is important to select factors that are as simple as possible, but which must make sense, linear models are recommended. Dealing with uncertainty is regarded as a fundamental principle of risk assessment and decision-making on prevention. The uncertainty of information about the past is discussed. The role of subjective risk assessment is emphasized and work with so-called sparse scales is outlined. Finally, examples from the Czech fire statistics are discussed. The paper was presented at the conference Crissiscon in Uherské Hradiště on 12 and 13 September in 2019.
\end{abstract}

Keywords: risk, prevention, information, reliability, subjective influence, fire statistics.

odvozen od mnoha faktorů, které se týkají hrozby, vlastního aktiva a prostředí, situace je schematizovaná na obr. 1. Neurčitost znamená možnost vzniku některého prvku definované množiny, s tím, že prvky mají určité vlastnosti, které tvoří podmnožiny. V problematice rizika, všechny prvky na schématu obr. 1, mimo známého CHA, jsou neurčité (pokud je za určité pokládáme, tak to je zjednodušení).

\section{NEURČITOST}

Problematika rizika je interdisciplinární, jednotlivé informace a vytvořené modely mají rozdílné neurčitosti. $\mathrm{V}$ tab. 1 je uvedeno třídění věd podle ČAV. 


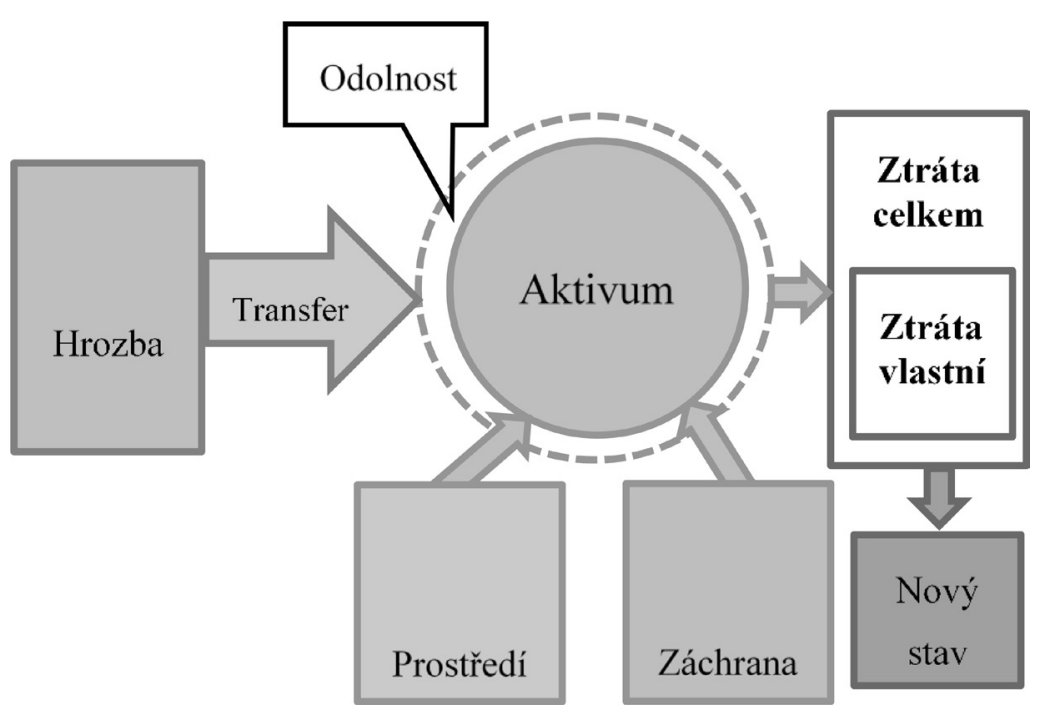

Obr. 1 Prvky ovlivňujici riziko.

Fig. 1 Elements affecting the risk.

Tab. 1 Trüiěni věd podle Akademie věd České republiky.

Tab. 1 Classification of sciences according to the Academy of Sciences of the Czech Republic.

\begin{tabular}{lcc}
\hline Vědní oblast & Míra opakovatelnosti experimentu & Neurčitost \\
\hline Neživá príroda & Vysoká & Velmi nízká \\
Živá př́roda a chemie* & Omezená & Přijatelná \\
Humanitní a společenské vědy & Velice nízká & Vysoká \\
\hline
\end{tabular}

*Zařazení chemie je poněkud specifické, poněvadž většina problémů je opakovatelných.

V problematice rizika se jedná společně o všechny 3 vědní oblasti. Minimální neurčitost je $\mathrm{v}$ technických disciplínách.

Neurčitost je v podstatě synonymum nespolehlivosti, respektive určitost - spolehlivost. Spolehlivost je spíše vnímána jako neurčitost chování lidí a používá se pro časové zachování funkce technických systémů.

Neurčitost má 2 složky:

- neurčitost jevu samého,

- neurčitost zjištění, měření.

Důležité jsou obě složky i jejich agregace, jejich oddělení je někdy snadné (např. počet požárů - zjištění bez chyby), jindy je složité, vyžaduje znalost neurčitosti zjištění, měření. Neurčitost hodnocení je všudypř́tomná a musíme s ní pracovat. Hodnocení je informací pro následné rozhodování a platí neurčité hodnocení - jednoznačné rozhodnutí ${ }^{1)}$.

Neurčitost hodnocení zahrnuje:

- neurčitost modelů rizika,

- neurčitost faktorů, informací.

Aditivní modely jsou užitečné, předpokládají nezávislost faktorů, kritérií a mají řadu dalších, dobrých vlastností. Př́ikladem jsou, převážně používané, empirické modely, např. model podle př́lohy vyhlášky č. 247/2001 Sb. [6] a výborného modelu

1) Příkladem je postup teorie fuzzy množin, která počíná fuzzyfikací a končí defuzzifikací autorského kolektive HZS Moravskoslezského kraje, publikované Krömer a kol. [3]. Při agregaci faktorů v modelech, platí, že s vyšším počtem faktorů roste absolutní chyba a proto je vhodné počet optimalizovat $\mathrm{z}$ hlediska neurčitosti (neplatí mnoho faktorů $=$ dobrý model).

\section{NEURČITOST FAKTORŮ RIZIKA}

Faktory hodnocení tvoříme na základě informací. Možnosti získání informací z časového hlediska jsou znázorněny na obr. 2.

Reálné informace jsou, vždy o něčem co bylo, i když se to odehrálo předem vteřinu. Informace o minulosti jsou reálné, ale jsou také neurčité. Neurčitost je většinou přirozená, ale někdy

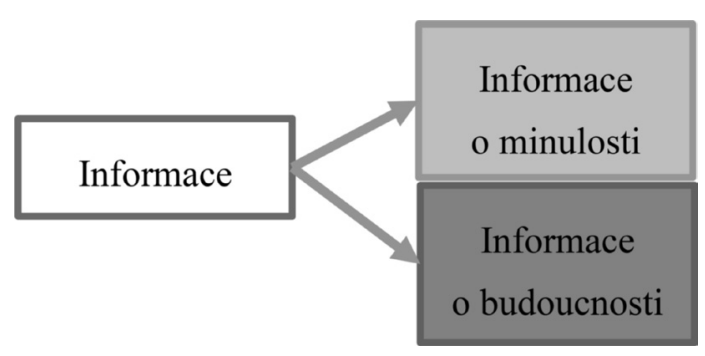

Obr. 2 Informace a čas.

Fig. 2 Information and time. 
s úmyslným zkreslením (např. fake news, prefabrikace osobností atd.). Informace o budoucnosti jsou pouze odhadem toho, co bude.

Použiváme faktory, které popisují:

- chráněná aktiva,

- minulost

- hmotné modelování,

- teoretické, abstraktní modelování,

- subjektivní hodnocení,

- kombinace.

Technikami posuzování rizik se zabývá ČSN 31010 [5], která je nepř́liš povedeným, především slovním textem. Neurčitostí se zabývá v kap. 5.3.6 na str. 17, která je zcela obecná.

Je nutné připomenout, že vyšší počet reálných či zvolených faktorů zvyšuje neurčitost agregací chyb, což platí u modelů aditivních i multiolikativních.

Nejjednodušší kvantifikaci rizika představuje hodnota CHA, kterou můžeme považovat za určitou. Něco jiného je předpokládaná míra poškození $\mathrm{CHA}$.

\section{INFORMACE O MINULOSTI A NEURČITOSTI}

Informace o minulosti, které zpracovávává statistika, mají časovou neurčitost velikosti $y$ a trend $b$, základní informace poskytuje lineární regrese, vyrovnané je:

$$
\hat{y}=a+b \cdot t \text {. }
$$

Informaci o neurčitosti poskytuje koeficient těsnost, či determinace:

$$
R^{2}=\frac{\sum \hat{y}^{2}}{\sum y^{2}} .
$$

Hodnoty $a, b$ a $R^{2}$ vypočte jednoduše EXEL.

Neurčitost informací v následné agregaci můžeme zohlednit dvojím způsobem:

- neurčité - nespolehlivé informace nepoužijeme,

- vypočteme výsledek pro očekávanou hodnotu a pro mezní hodnoty (viz obr. 3 ).

Nespolehlivost posuzujeme podle relativní neurčitosti $\delta$, meze přijatelnosti stanovíme dle uvážení. V praxi většinou za nespolehlivé považujeme informace s $\delta>0,2(20 \%)$. Relativní neurčitost respektující časové změny je

$$
\delta=\frac{2 \cdot s_{Y} \cdot \sqrt{1-R^{2}}}{\bar{Y}},
$$

kde:

$$
\begin{array}{ll}
s_{Y} & \text { směrodatná odchylka } Y, \\
Y & \text { průměr } Y .
\end{array}
$$

Zásadní pro použití informací z minulosti je neurčitost, daná extrapolací. Trend může být zachován, nebo se mění, kladně či záporně. Není jiné řešení, než kvalifikovaný odhad extrapolace.

Hmotné modelování můžeme realizovat v technické problematice, je velmi spolehlivé, protože řešení můžeme opakovat. Např. opakovaně můžeme ověřit hořlavost textilií, proudění kouře atd. Spolehlivost experimentu je dána vytvořením a zachováním vnějších podmínek a počet opakování. Hmotné modelování použivejme všude, kde je možné.

Teoretické, abstraktní modelování faktorů vychází z kontinuálních zkušeností a je podporou myšlení. Einstein $\mathrm{k}$ tomu napsal (viz [2], str. 39)

$$
\begin{gathered}
\text { „Věda jako taková není nic jiného než zpřesňování } \\
\text { každodenního myšlení.“ }
\end{gathered}
$$

Neurčitost abstraktního modelování není univerzální, lze ji hodnotit podle opakovatelnosti výsledků modelů. Školním př́ikladem je nespočitatelně opakované vytvoření pravého úhlu, které zná každý tesař, trojúhelník o odvěsnách $3 \mathrm{~m}$ a $4 \mathrm{~m}$ a přeponě $5 \mathrm{~m}$ tvoří pravý úhel mezi odvěsnami, je to známá Pythagorova věta. $\mathrm{V}$ mnoha př́padech není opakovatelnost $\mathrm{k}$ dispozici a musíme vycházet pouze z vlastní úvahy. Dobrou metodou je použití více modelů a posouzení výsledků.

\section{SUBJEKTIVNÍ HODNOCENÍ}

Subjektivní hodnocení rizika je frekventovanou metodou. Název subjektivní hodnocení není zcela odpovídající, poněvadž většinou jej provádí odborníci, experti, kteří do svých výroků zahrnují i další znalosti. Psychologové dlouhodobě zkoumají možnosti vnímání (viz Atkinson [1]), platí WEBER - Fechtnerův zákon o relativním vnímání změn $\delta$, nap̌r. světlo $8 \%$, zvuk $5 \%$, pach $15 \%$. Pro praktickou orientaci můžeme zjednodušeně předpokládat rozlišitelnost $\delta=0,1$ [1], tj. 10\%. Připomeňme, že neurčitost vnímáme relativně - řešíme absolutně.

Dále byla věnována pozornost možnosti kvantifikace jevů, která je možná na tzv. ř́́dkých stupnicích max. do 12 bodů, prakticky 1 . řádem (do 10). Na obr. 4 je znázorněna relativní chyba zápisu 1-10.

Americký psycholog Likert v 30. letech 20. století navrhl používání 5 bodové stupnice, což je prakticky vhodné (viz porovnání s obr. 4).



Obr. 3 Meze neurčitosti.

Fig. 3 Limits of uncertainty. 


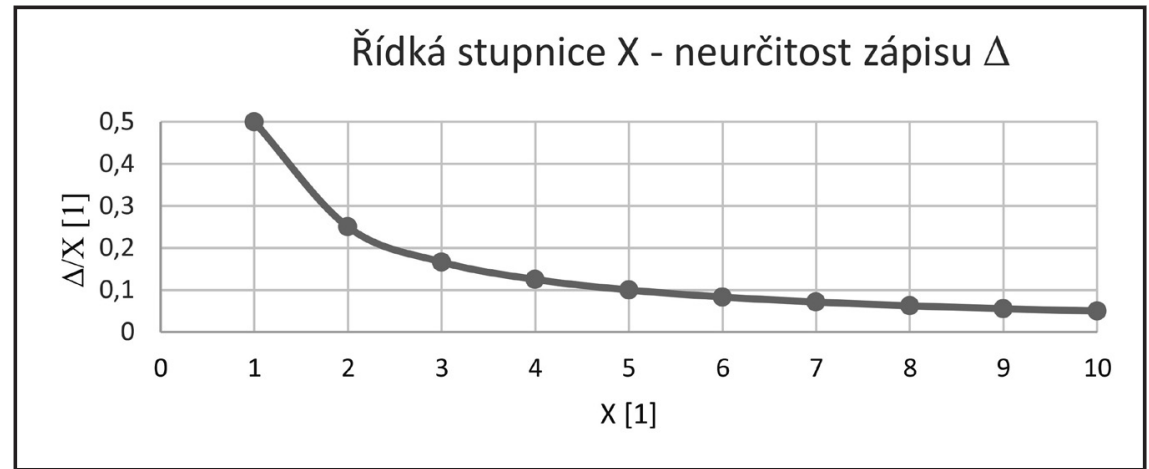

Obr. 4 Relativní chyby zápisu.

Fig. 4 Relative write error.

Stupnice subjektivního hodnocení expertů nelze analyzovat momentovými charakteristikami, např. průměrem, poněvadž ten kdo hodnotí 5 body nemá $5 \times$ vyšší význam, než ten který hodnotí 1 bodem. Použiváme četnostní analýzu distribuční funkce. Posouzení neurčitosti subjektivního hodnocení vychází z kvantilů distribuční funkce. Významné jsou kvartily, ukazatelem polohy je medián $\tilde{\boldsymbol{x}}$. Absolutní ukazatele neurčitosti jsou:

$$
\Delta^{\Sigma}=x(75)-x(25),
$$

což popisuje interval neurčitosti $50 \%$ respondentů. Relativně vzhledem rozsahu řídké stupnice $n$ je neurčitost:

$$
\delta^{\Sigma}=\frac{\Delta^{\Sigma}}{n}
$$

Nesymetrii neurčitosti vyjadřují absolutně:

$$
\begin{aligned}
& \Delta^{+}=x(75)-\tilde{x}, \\
& \Delta^{-}=\tilde{x}-x(25) .
\end{aligned}
$$

Obdobně relativní nesymetrie jsou:

$$
\begin{gathered}
\delta^{+}=\frac{\Delta^{+}}{n}, \\
\delta^{-}=\frac{\Delta^{-}}{n} .
\end{gathered}
$$

Postup práce s neurčitostí je obdobný, jak bylo uvedeno u informací z minulosti. Za hraniční považujeme kvartily $x(25)$ a $x$ (75). Bud' vyřadíme hodnocení:

$$
\Delta^{\Sigma}>\frac{n}{2}
$$

kde:

$n$ počet bodů řídké stupnice, nebo vypočteme agregace s mezními hodnotami a následně se rozhodujeme.

\section{VÝBĚR FAKTORŮ}

Faktorů, které můžeme použít při tvorbě modelů rizika je mnoho, viz obr.1. Prakticky použijeme pouze omezené množství a výběr faktorů závisí na jejich smyslu a důvěryhodnosti, dané neurčitostí.
Tab. 2 Neurčitost zdrojů a použití - hodnocení rizika. Tab. 2 Uncertainty of sources and uses - risk assessment.

\begin{tabular}{lccc}
\hline \multicolumn{2}{c}{ Zdroj faktorů } & \multicolumn{2}{c}{ Určitost } \\
& & Zdroje & Použití \\
\hline Chráněné aktivum & & ++ & ++ \\
Minulost - statistika & + & - \\
Modelování & Hmotné & ++ & ++ \\
Subjektivní hodnocení & Abstraktní & + & - \\
\hline & & - & - \\
\hline \multirow{2}{*}{ Určitost } & Relativní & \multicolumn{3}{c}{ Silná } \\
Neurčitost & + & \multicolumn{3}{c}{++} \\
\hline
\end{tabular}

Možné schéma neurčitosti při hodnocení rizika je uvedeno v tab. 1. Vysoká určitost je při použití údajů o hodnotě, významu aktiva a při materiálním modelování. Ostatní zdroje jsou neurčité, použití pojmu „relativní" vyjadřuje závislost na konkrétních okolnostech. Např. expertní hodnocení může být velice spolehlivé i nespolehlivé. Spolehlivost zdrojů i modelů

posuzujeme na základě neurčitosti a opakovatelnosti.

\section{PŘÍKLAD - HODNOCENÍ POŽÁRŮ}

Jako př́klad posouzení informací z minulosti uvedeme analýzu požárů. Rozsáhlé informace o mimořádných událostech ČR, zejména požárech, jsou k dispozici v Statistických ročenkách HZS. V dalším byla použita Statistická ročenka 2018 [7]. Počet MU za období 1997 - 2018 je uveden na obr. 5.

Z časového průběhu je zjevné, že rok 2003 byl mimořádný, pro dlouhodobé hodnocení je vhodné 2003 vyřadit, ale vzhledem k hodnoceným 21 rokům se výsledek změní málo. Regresní analýza dává informaci, že průměrně došlo k poklesu požárů o 200 [1/rok], což je nevýznamné, cca $1 \%$, statisticky, viz $\mathrm{R}^{2}$, považujeme počet požárů za konstantní. Jedná se o informaci podporující rozhodnutí o dalším postupu, můžeme to považovat za uspokojivé, nebo požadujeme zlepšení a rozhodujeme o opatřeních.

Dalším př́ikladem je analýza požárů v letech 2014 - 2018 podle odvětví. 


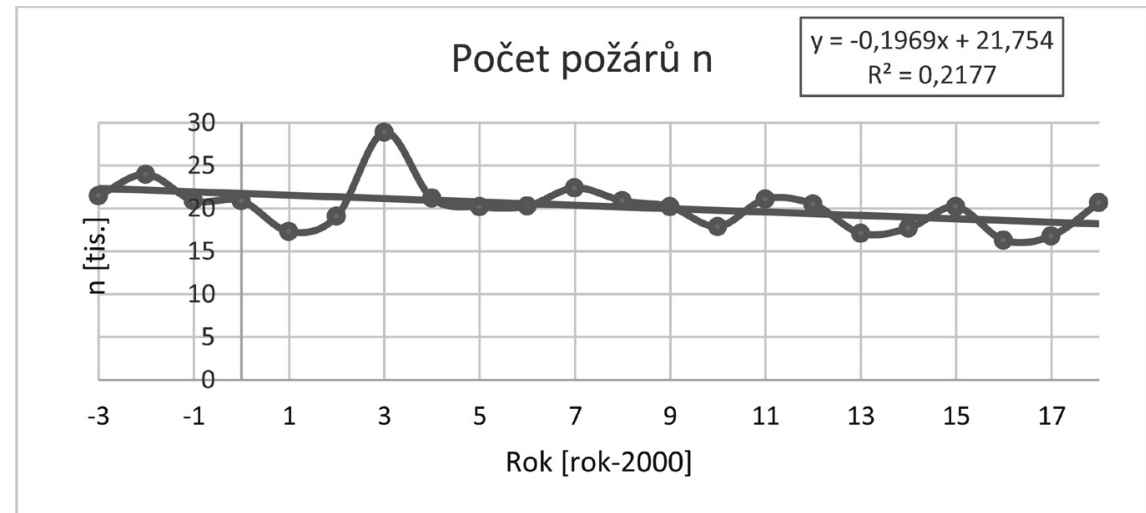

Obr. 5 Počet požárů.

Fig. 5 Number of fires.

Tab. 3 Časová analýza požárů [mil. Kč] v odvětvích.

Tab. 3 Time analysis of fires [bil. Kč] in sectors.

\begin{tabular}{|c|c|c|c|c|c|c|c|}
\hline Odvětví & Průmysl & Stavebnictví & Zemědělství & Doprava & Obchod & Restaurace & Domácnost \\
\hline $\mathrm{b}$ & 94,6 & $-0,154$ & 20,3 & $-2,1$ & 0,599 & 4,36 & 41 \\
\hline $\mathrm{a}$ & 781,3 & 21,1 & 91,8 & 40,1 & 96,1 & 6,09 & 203 \\
\hline $\mathrm{R}^{2}$ & 0,068 & 0,001 & 0,54 & 0,0012 & 0,001 & 0,135 & 0,832 \\
\hline
\end{tabular}

$\mathrm{V}$ tab. 3 je $\mathrm{b} \ldots$ trend $[1 / \mathrm{rok}]$, a ... pro $t=0, \mathrm{R} \ldots$ koeficient těsnosti či determinace.

Mimo dopravy a domácností nelze ze statistických údajů vyvodit závěry pro další opatření. Musíme použít jiné hodnocení, např. expertní. Opatření zjevně vyžaduje doprava a domácnosti.

\section{ZÁVĚR}

Pojem rizika se vztahuje $\mathrm{k}$ budoucnosti a $\mathrm{k}$ újmě na chráněném aktivu. Použití pojmu riziko je často zkreslováno a zahrnuje i sekvence již vzniklé nežádoucí situace. Riziko samozřejmě ovlivňuje hrozba a řada dalších okolností, jak je uvedeno na obr. 1 . Hodnocení rizika a návrh prevence je silně interdisciplinární záležitost. Zásadním problémem při práci s rizikem je neurčitost, která je relativně malá u technických věd a velká u věd společenských, jinak řečeno, velkou neurčitost způsobuje vliv člověka.

Větší počet faktorů a složitější modely způsobují vyšší neurčitost a proto je vhodné volit co nejméně faktorů a jednoduché modely, ovšem v míře přijatelné pro řešení úlohy. Pro hodnocení minulosti je vhodná lineární regrese. Hodnocení rizika je silně ovlivněno subjektivně. Pro kvantifikaci se používají tzv. ř́́dké stupnice, nejčastější je 5 bodoví Likertova škála. Situaci musíme vždy posoudit tzv. „zdravým rozumem“. Pojednání upozorňuje na nutnost zohlednit při hodnocení rizika neurčitost faktorů a modelů.

\section{LITERATURA}

[1] ATKINSON, R. et al. Psychologie. Portál s.r.o., 2003, Praha, 750 s. ISBN 80-7178-640-3.

[2] EINSTEIN A. Z mých pozdějšich let. Praha: Nakladatelství Lidové noviny, 1995. ISBN 80-7106-116-6.

[3] KRÖMER, A. et al. Mapování rizik. SPBI, 2010, Ostrava, $126 \mathrm{~s}$. ISBN 978-80-7385-086-9.

[4] ČSN ISO 31000, Management rizik - Směrnice. Praha: Úřad pro technickou normalizaci, metrologii a státní zkušebnictví, 2018.

[5] ČSN ISO 31010, Management rizik - Techniky posuzování rizik. Praha: Úřad pro technickou normalizaci, metrologii a státní zkušebnictví, 2011.

[6] Vyhláška 247/2001Sb., aktualizace 226/2005 Sb. o organizaci a činnosti jednotek požární ochrany.

[7] HZS ČR. Statistická ročenka 2018 ČR [online]. GŘ HZS ČR, 2018 [cit. 2019-25-11]. Dostupné z: https://www.hzscr.cz/clanek/ statisticke-rocenky-hasicskeho-zachranneho-sboru-cr.aspx

[8] ROUDNÝ, R. Spolehlivost analýzy rizika. In: Př́spěvky konference CRISCON 2019, FLKŘ UTB ve Zlíně, 2019, 6 s.

\section{Správná citace:}

ROUDNÝ, R. Spolehlivost analýzy rizika. Soudní inženýrství, 2019, 30(4), 53-57. DOI: http://dx.doi.org./10.13164/SI.2019.4.53. ISSN 1211-443X. 